\title{
803 テーラードブランク材のインクリメンタル成形の数值的検討 Numerical Simulation of Incremental Forming of Tailored Blank
}

\author{
正○ 山下実(岐阜大工) 正 服部敏雄(岐阜大工) 正 西村尚哉(岐阜大工） 学 山田賢治(岐阜大院)
}

Minoru YAMASHITA, Toshio HATTORI, Naoya NISHIMURA, Kenji YAMADA, Gifu University, 1-1 Yanagido, Gifu

Key Words : Talored Blank, Joint Line, Incremental Forming, Numerical Simulation, Sheet Metal

\section{1. 緒言}

製品の多品種化および開発・設計期間の短縮化の要求に答 えるため, 金属板製品の加工法としてインクリメンタル成形 法が注目され，多くの実験的研究がなされているたとえば,1,2). この成形法においては，変形部は成形工具周辺に限られるも のの, 成形工具の移動経路に応じた複雑なひずみ履歷を生じ る，著者らは，実験と数值計算で同成形法おける各種影響因 子が成形性に及ぼす影響について検討してきた ${ }^{3,4)}$.

本報では, インクリメンタル成形の適用範囲拡大を狙って, テーラードブランクを成形素材とした．特に素材強度が変化 する継合せ部近傍の変形に注目して数值計算で基礎的検討を 行った. 成形形状は半円断面の真直溝と四角形容器とした.

\section{2. 計算条件}

使用したソルバーは動的陽解 FEM コード DYNA3D(Public domain version)である ${ }^{5)}$. 計算モデルの例として, 半円断面の 真直溝のインクリメンタル成形のものを図 1 に示す. 被加工 材料の板厚方向の変形も詳細に検討できるように, 8 節点ソ リッド要素を用いて板厚方向は 4 層に分割した。 その外周節 点で変位および回転運動を拘束した。被加工材料は弾塑性を 仮定し, 塑性特性は $n$ 乗硬化型とした。各種特性を表 1 に示 す. 被加工材料は板厚 $0.25 \mathrm{~mm}$, 一辺 $14.5 \mathrm{~mm}$ の正方形板で, 中央対称線上に継合せ部がある．塑性係数を一定 $(300 \mathrm{MPa})$ と して,$n$ 值を変えて塑性特性に差を与えたブランク,$n$ 值を一 定として塑性係数を変えたものについて計算した.

成形工具の先端は半径 $1 \mathrm{~mm}$ の半球形状で, 剛体を仮定し 4 節点シェル要素で表した. 成形工具の速度を $20 \mathrm{~m} / \mathrm{s}$ と設定し て計算効率を上げた。この程度の速度域までは慣性が変形に 及ぼす影響は限定的であることが，著者の一人によって確認 されている ${ }^{3)}$.

一方, 固定工具の正方形穴の対辺長さは $12.5 \mathrm{~mm}$ であり, 板と接する箇所の丸み部半径は $1 \mathrm{~mm}$ とした. 固定工具も剛 体とした. 工具と材料間の摩擦は無視した. 以上の条件は, 後述の溝および四角筒容器の成形に共通である.

\section{3. 真直溝の成形における継合せ部の変形挙動}

被加工材の塑性特性の影響を検討しやすくするため, 成形 形状は半円断面の真直溝形状(深さ $2 \mathrm{~mm}$ ) とした. 成形工具を 板面に $0.5 \mathrm{~mm}$ 垂直に押込んだ後, 板面と平行に $6 \mathrm{~mm}$ 移動さ せ，そこで再度押込んで平行移動させる経路を繰返して溝を 成形した(図 1 参照). 成形工具が継合せ部を垂直に横切る経 路と初期の継合せ線上を移動する経路について検討した。

まず，前者の工具経路について，最終形状における板厚ひ ずみ分布と断面形状を図 2 に示す. 塑性係数を一定として加 工硬化指数が異なる板を成形する場合，加工硬化指数の大き い材料で塑性変形の伝播性が高いことは, 溝端部の押込み位 置付近の板厚ひずみに顕著に現れた。また，継合せ部付近の 板厚ひずみに関しては, 溝部での板厚ひずみの差異はあまり ないものの, 溝周辺の継合せ部に沿ってひずみの変化が大き い領域が見られた。垂直断面形状については，いずれの条件 でもほぼ同様であり，全体形状に及ぼす影響は小さいと言え
る.

また, 加工硬化指数を一定とした場合, 塑性係数の差が大 きくなると, 溝部の継合せ部で板厚ひずみの不均一が目立つ た。また, 垂直断面形状の溝底部において; 継ぎ目付近では うねりを生じており, 形状精度の低下も見られた.もちろん， 変形抵抗の差が継ぎ目近傍のひずみ举動に影響するが，ここ で設定した $n$ 值ではひずみがある程度の大きさになると現れ にくかった，継合せた材料の変形抵抗の差が大きい場合，継 合せ近傍は板厚が局所的に薄くなるという点で破断危険部位 と言える。

つぎに，成形工具を初期の継合せ線上を移動させた場合に ついて，板厚ひずみ分布と断面形状を図 3 に示す。変形抵抗 の小さい材料側で変形が大きく，継合せ部が図中では左側に 移動しており，前述の場合と同様，継ぎ目に沿って線状にひ ずみの大きい領域が現れた．また，成形工具が当たっていな い板面側には顕著な段差が現れた．板厚ひずみについては, この場合, -1.47 が最小であった. 成形工具が継ぎ目を横断し て成形する場合では， -0.73 であり，継ぎ目方向に対する成形 工具移動方向の影響は顕著であるといえる.

\section{4. 四角形容器の成形における継合せ部の変形挙動}

工具等の各寸法と成形工具経路を図 4 および 5 にそれぞれ 示す. 成形工具の先端半径は $1 \mathrm{~mm}$ である. 成形工具は, 板 面に $1 \mathrm{~mm}$ 押込まれた後, 外側から中心几と渦巻状に移動し, 中心で再び $1 \mathrm{~mm}$ 押込まれて, 渦巻状に外側へ移動して戻っ てくる，すなわち，成形工具の押込み深さは $2 \mathrm{~mm}$ である. 成形工具は，継ぎ目を横断して移動する.

板厚ひずみ分布を図 6 に示す．工具経路と継ぎ目線の関係

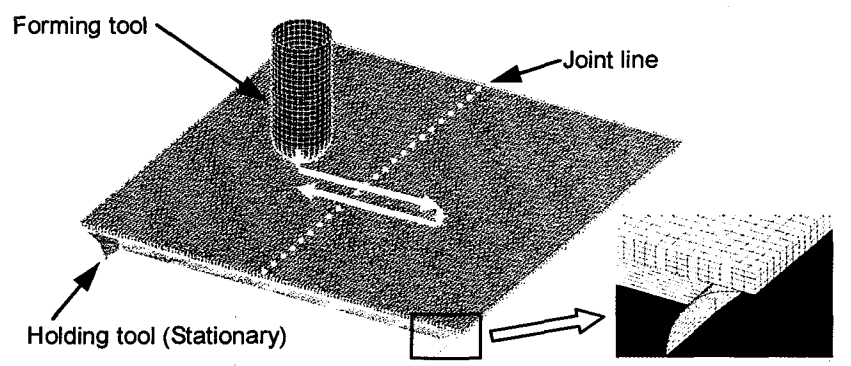

Fig. 1 Numerical model for the forming of straight groove, where the punch locates at the initial position traveling across the joint line.

Table 1 Specifications of sheet material.

\begin{tabular}{|c|c|}
\hline Density & $2700 \mathrm{~kg} / \mathrm{m}^{3}$ \\
\hline Young's modulus & $72 \mathrm{GPa}$ \\
\hline Poisson's ratio & 0.33 \\
\hline Plastic property & $\sigma=c \varepsilon^{n}$ \\
\hline $\begin{array}{c}\text { Combinations of } \\
c \text { and } n \text {-values of } \\
\text { tailored blank }\end{array}$ & $\begin{array}{c}n_{1}=0.30 \text { and } n_{2}=0.10,0.20,0.30 \\
\text { under } c=300 \mathrm{MPa} \text { (const.) } \\
c_{1}=300 \text { and } c_{2}=100,200,250,300 \\
\text { under } n=0.30 \text { (const.) }\end{array}$ \\
\hline
\end{tabular}


が同じ図 2(b)の場合と同様に継ぎ目部近傍でひずみの変化が 目だった．側面形状については，強度差が大きいと継ぎ目で はっきりと段差を生じた. また，この成形における全体とし ての変形領域は溝成形のものより広く, 深さが同じにもかか わらず, 最小のひずみは-0.97で図 2(b)の-0.73よりも小さかっ た.

\section{参考文献}

1) 井関日出男他 : 塑性と加工，38-438 (1997)，611.

2) 松原茂夫 : 塑性と加工, 42-489(2001), 991.
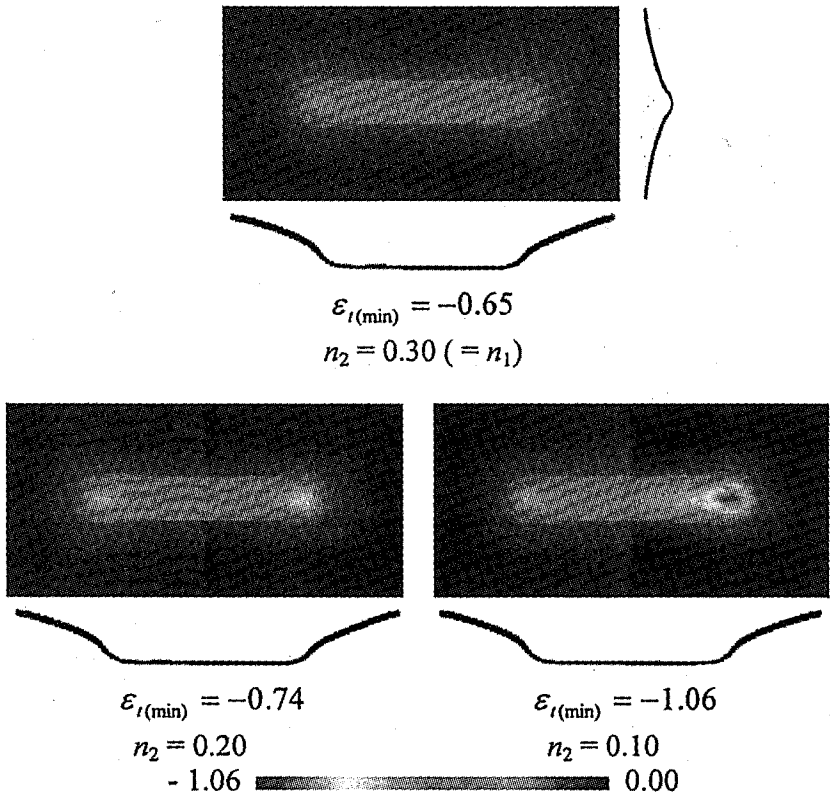

(a) The case where the strain hardening exponent varies $n_{1}=0.30$ for the left half of the sheet, $c=300 \mathrm{MPa}$ in all cases
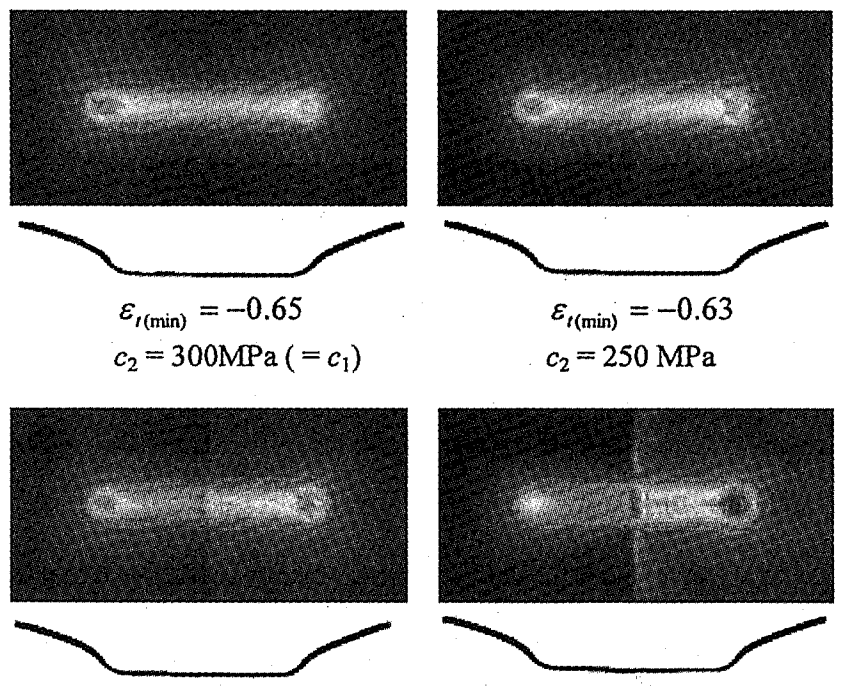

$\varepsilon_{t(\min )}=-0.63$

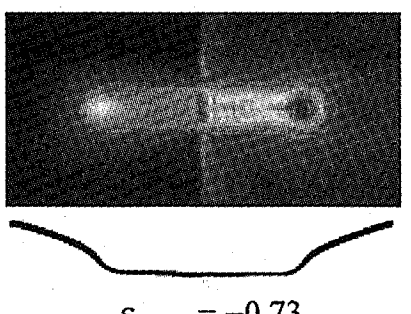

$c_{2}=200 \mathrm{MPa}$

$\varepsilon_{t(\min )}=-0.73$

$-0.73$

$c_{2}=100 \mathrm{MPa}$

(b) The case where the plastic constant varies $c_{1}=300 \mathrm{MPa}$ for the left half of sheet, $n$-value $=0.30$ in all cases

Fig. 2 Distribution in thickness strain of the forming of groove where the forming tool travels across the joint line.
3) 山下実他 : 54 回塑性加工連合講演会論文集,(2003), 431.

4) 山田賢治他，機械学会東海支部 55 期論文集 063-1, (2006), 183.

5) DYNA3D User's manual, 1989.
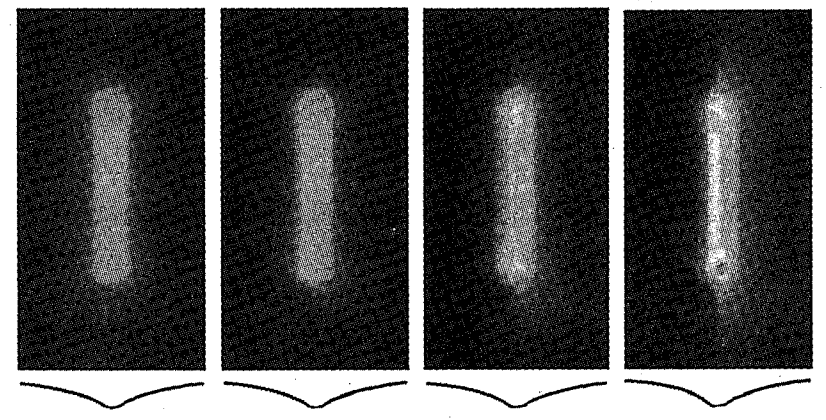

$\varepsilon_{t(\min )}=-0.65$

$-0.81$

$-1.04$

$-1.47$

$c_{2}=300 \mathrm{MPa}\left(=c_{1}\right) \quad 250 \mathrm{MPa}$

$200 \mathrm{MPa}$

$100 \mathrm{MPa}$

Fig. 3 Distribution in thickness strain of the forming of groove where the forming tool travels along the joint line.

$c_{1}=300 \mathrm{MPa}$ for the left half of sheet, $n$-value $=0.30$ in all cases
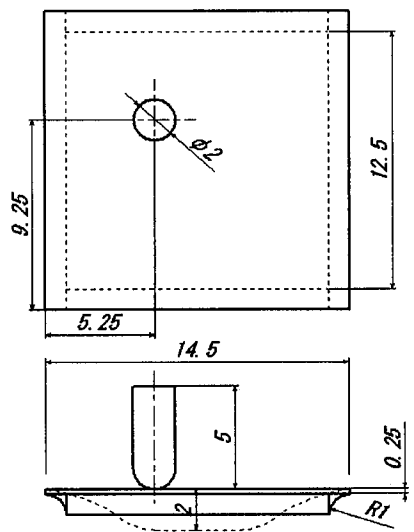

Fig. 4 Dimensions in the incremental forming of square cup.

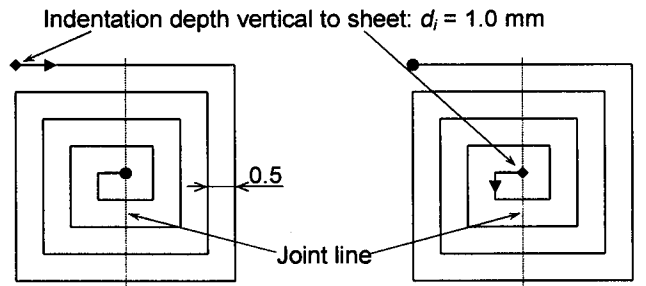

Fig. 5 Tool path along sheet plane with two times of indentation.
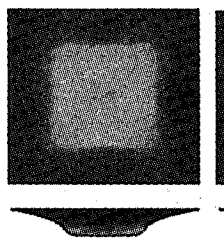

$\varepsilon_{t(\min )}=-0.56$

$-0.62$
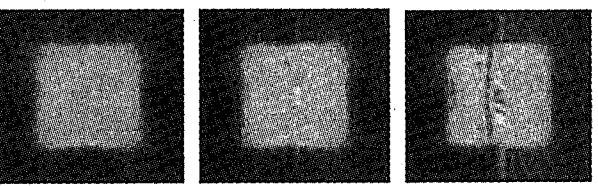

$c_{2}=300 \mathrm{MPa}\left(=c_{1}\right) \quad c_{2}=250 \mathrm{MPa}$

-0.97 o.

Fig. 6 Distribution in thickness strain for the forming of square cup. $c_{1}=300 \mathrm{MPa}$ for the left half of sheet, $n$-value $=0.30$ in all cases 